\title{
An Efficient Synthesis of Novel Adamantane $\beta$-Amino Acid: 2-(Adamant-2-yl)-3-aminopropanoic Acid ${ }^{\dagger}$
}

\author{
Vesna Petrović Peroković, Rosana Ribić, ${ }^{*}$ Biserka Prugovečki, \\ Dubravka Matković-Čalogović, and Srđanka Tomić
}

Department of Chemistry, Faculty of Science, University of Zagreb, Horvatovac 102a, 10000 Zagreb, Croatia

RECEIVED JULY 4, 2012; REVISED AUGUST 18, 2012; ACCEPTED AUGUST 19, 2012

\begin{abstract}
Novel adamantane-containing $\beta$-amino acid, 2-(adamant-2-yl)-3-aminopropanoic acid, interesting from the aspect of medicinal chemistry, was prepared and characterized. It was synthesized in a sequence of three steps with very good overall yield. In the first step ethyl adamant-2ylidenecyanoacetate was prepared and its crystal structure was determined. Reduction of this unsaturated cyanoacetate by catalytic hydrogenation gave the ethyl ester of the desired amino acid. 2-(Adamant-2-yl)3-aminopropanoic acid was obtained following ester hydrolysis. (doi: 10.5562/cca2122)
\end{abstract}

Keywords: adamantane, $\beta$-amino acid synthesis, nitrile reduction, crystal structure

\section{INTRODUCTION}

The adamantyl group is present in seven compounds in current clinical use for the treatment of neurodegenerative disorders, viral infections and type 2 diabetes, and in many more substances that are in development as potential therapeutics. ${ }^{1}$ In many cases the adamantyl group has been found to improve pharmacological properties of a parent compound, without increasing its toxicity. Incorporation of a bulky lipophilic adamantyl moiety into compounds increases their biological availability by inducing greater membrane permeability and/or decreasing the susceptibility to hydrolytic enzymes (amidases, esterases). ${ }^{2-5}$

Adamantyl-containing compounds are utilized for a number of applications in medicinal chemistry. One of the applications is the modification of biologically active peptides, such as neuropeptides (enkephalines, vasopresins $)^{6-8}$ and immunologically active muramyl dipeptides, ${ }^{9}, 10$ by using amino acids containing the adamantane moiety. On the other hand, preparation of artificial peptides is useful for the study of peptidereceptor interactions since the unnatural amino acids cause modifications in the peptide conformation. Especially interesting are those featuring bulky substituents, such as adamantyl, which cause the decrease of conformational mobility of peptides. ${ }^{11-13}$ Adamantylglycines (with adamant-1-yl and adamant-2-yl substitents), ${ }^{14,15}$ 2-aminoadamantane-2-carboxylic acid, ${ }^{16} \gamma$-aminoada- mantane carboxylic acid $^{17}$ are adamantane-containing amino acids used for these purposes.

As a part of the project directed towards the preparation of adamantyl desmuramyldipeptides we report here an efficient synthesis of novel adamantane-based $\beta$-amino acid, 2-(adamant-2-yl)-3-aminopropanoic acid. Since relatively small changes in the primary structure of adamantyl desmuramyldipeptides (linkage of the peptide portion at $\mathrm{C}(1)$ or at $\mathrm{C}(2)$ of adamantyl moiety) $)^{9,10}$ affect their immune reaction we were encouraged to synthesize the new unnatural amino acid of the adamantane type for further structure-activity studies. Crystal structure of ethyl adamant-2-ylidenecyanoacetate, used as the precursor in the synthesis, is also described.

\section{EXPERIMENTAL}

\section{General Remarks}

The chemical reagents used in syntheses were obtained from Fluka and Aldrich Corp. All solvents were purified using standard procedures. Thin layer chromatography (TLC, solvents and proportions are given in the text) was performed on Fluka silica gel (60 F 254) plates $(0.25 \mathrm{~mm})$. Visualization was effected by use of UV light, iodine and ninhydrin. Melting points were determined in open capillaries using Büchi B-540 melting point apparatus and are uncorrected. IR spectra were recorded using Perkin Elmer FT-IR Spectrometer

\footnotetext{
$\dagger$ This article belongs to the Special Issue devoted to the $85^{\text {th }}$ anniversary of Croatica Chemica Acta.

* Author to whom correspondence should be addressed. (E-mail: rribic@chem.pmf.hr)
} 
Spectrum Two. ${ }^{1} \mathrm{H}$ and ${ }^{13} \mathrm{C}$ NMR spectra were recorded with Bruker Avance spectrometer at room temperature at $300 \mathrm{MHz}$ and $75 \mathrm{MHz}$, respectively. Chemical shifts are given in ppm downfield from TMS as internal standard. Electrospray ionization mass spectrometry (ESI-MS) was performed using Agilent 6410 MS instrument. High resolution mass spectra (HRMS) were obtained by matrix-assisted laser desorption/ionizationtime-of-flight MALDI-TOF/TOF mass spectrometer (4800 Plus MALDI TOF/TOF analyzer, Applied Biosystems Inc., Foster City, CA, USA) equipped with $\mathrm{Nd}$ :YAG laser operating at $355 \mathrm{~nm}$ with firing rate $200 \mathrm{~Hz}$ in the positive ion reflector mode.

\section{Synthesis}

Ethyl adamant-2-ylidenecyanoacetate (1)

2-Adamantanone (1 g, $6.66 \mathrm{mmol})$ and ethyl cyanoacetate $(0.71 \mathrm{~mL}, 6.66 \mathrm{mmol})$ were dissolved in dry benzene $(20 \mathrm{~mL}) . \mathrm{NH}_{4} \mathrm{OAc}(0.10 \mathrm{~g}, 1.33 \mathrm{~mol})$ and concentrated HOAc (1.05 mL, $5.33 \mathrm{~mol})$ were then added. Reaction mixture was refluxed in Dean-Stark apparatus for $24 \mathrm{~h}$. The mixture was diluted with benzene and extracted with water. The organic layer was concentrated under the reduced pressure giving yellow oil. $70 \%$ EtOH (aq) was added and white solid precipitated from the solution after cooling. Recrystallization from ethanol/water gave colourless crystals $(1.5 \mathrm{~g}, 91 \%) ; R_{\mathrm{f}}=0.57$ (petroleum ether/diethyl ether $=$ 2:1); m.p. $79-80{ }^{\circ} \mathrm{C}$ (lit. $\left.81-82{ }^{\circ} \mathrm{C}\right) .{ }^{18}$ IR (KBr) $v_{\max } / \mathrm{cm}^{-1}: 2983,2931,2857(\mathrm{C}-\mathrm{H}), 2221(\mathrm{CN}), 1725$ $(\mathrm{C}=\mathrm{O}), 1593(\mathrm{C}=\mathrm{C}) .{ }^{1} \mathrm{H}$ NMR $\left(\mathrm{CDCl}_{3}\right) \delta / \mathrm{ppm}: 4.27$ (q, 2H, $\left.J=7.2 \mathrm{~Hz}, \mathrm{OCH}_{2}\right), 2.13-1.84(\mathrm{~m}, 14 \mathrm{H}, \mathrm{Ad})$, $1.36\left(\mathrm{t}, 3 \mathrm{H}, J=7.1 \mathrm{~Hz}, \mathrm{CH}_{3}\right) .{ }^{13} \mathrm{C} \mathrm{NMR}\left(\mathrm{CDCl}_{3}\right)$ : 188.72 (CO), $162.14(\mathrm{C}=\mathrm{C}, \mathrm{Ad}), 115.53(\mathrm{CN}), 98.17$ $(\mathrm{C}=\mathrm{C}(\mathrm{CN}) \mathrm{COOEt}), 61.56\left(\mathrm{OCH}_{2}\right), 40.05,39.66,36.12$ $\left(\mathrm{CH}_{2}, \mathrm{Ad}\right), 40.09,34.44,27.18(\mathrm{CH}, \mathrm{Ad}), 14.05\left(\mathrm{CH}_{3}\right)$. ESI-MS: $[\mathrm{M}+\mathrm{H}]^{+} \mathrm{m} / \mathrm{z} 246.4$.

\section{Ethyl 2-(adamant-2-yl)-3-aminopropanoate (2)}

To a solution of compound $1(200 \mathrm{mg}, 0.82 \mathrm{mmol})$ in $\mathrm{MeOH}(15 \mathrm{~mL}) 10 \% \mathrm{Pd} / \mathrm{C}(40 \mathrm{mg})$ and concentrated $\mathrm{HCl}(0.28 \mathrm{~mL})$ were added. The mixture were subjected to hydrogen atmosphere under 40 PSI at room temperature and stirred for $6 \mathrm{~h}$. Then the catalyst was filtered off and the filtrate concentrated under reduced pressure. The resulting oil was suspended in water and extracted with diethyl ether in order to remove the unreacted compound 1. The aqueous layer was then treated with $2 \mathrm{M} \mathrm{NaOH}(\mathrm{pH} \mathrm{12)}$, extracted with ethyl acetate and organic layers dried over anhydrous $\mathrm{Na}_{2} \mathrm{SO}_{4}$. After filtration, the organic layer was concentrated in vacuo and the product $2(175 \mathrm{mg}, 85 \%)$ was obtained as a colourless oil. $R_{\mathrm{f}}=0.45\left(\mathrm{CHCl}_{3} / \mathrm{MeOH}=4: 1\right)$. IR $(\mathrm{KBr})$ $v_{\max } / \mathrm{cm}^{-1}: 3378,3309(\mathrm{~N}-\mathrm{H}$ stretch), 2907, $2852(\mathrm{C}-\mathrm{H})$, $1728(\mathrm{C}=\mathrm{O}), 1599(\mathrm{~N}-\mathrm{H}$ bend $)$.
${ }^{1} \mathrm{H}$ NMR $\left(\mathrm{CDCl}_{3}\right)$ : 4.22-4.12 (m, $\left.\mathrm{OCH}_{2}\right), 2.96-2.82$ (m, 3H, CH- $\alpha, \mathrm{C}_{2} \mathrm{NH}_{2}$ ), 2.03-1.52 (m, 17H, Ad, $\mathrm{NH}_{2}$ ), $1.27\left(\mathrm{t}, 3 \mathrm{H}, J=7.1 \mathrm{~Hz}, \mathrm{CH}_{3}\right) .{ }^{13} \mathrm{C} \mathrm{NMR}\left(\mathrm{CDCl}_{3}\right)$ : $175.72(\mathrm{CO}), 60.09\left(\mathrm{OCH}_{2}\right), 50.30(\mathrm{CH}-\alpha), 44.35(\mathrm{CH}$, Ad), $42.25\left(\mathrm{CH}_{2} \mathrm{NH}_{2}\right), 38.88,38.09,31.87,31.53\left(\mathrm{CH}_{2}\right.$, Ad), 30.95, 28.83, 27.94, $27.67(\mathrm{CH}, \mathrm{Ad}), 14.35\left(\mathrm{CH}_{3}\right)$. ESI-MS: $[\mathrm{M}+\mathrm{H}]^{+} \mathrm{m} / z 252.2$.

\section{2-(Adamant-2-yl)-3-aminopropanoic acid (3)}

Compound 2 (70 mg, $0.28 \mathrm{mmol}$ ) was dissolved in a 1:2 mixture of dioxane / $2 \mathrm{M} \mathrm{NaOH}(6 \mathrm{~mL})$. Reaction mixture was stirred at room temperature for $48 \mathrm{~h}$ and monitored by TLC $\left(\mathrm{CHCl}_{3} / \mathrm{MeOH}=4: 1\right), R_{\mathrm{f}}$ value of product 3 was 0.10 . Reaction mixture was then treated with $2 \mathrm{M} \mathrm{HCl}(\mathrm{pH} \sim 6)$ and product 3 precipitated as a white solid (56 mg, $90 \%$ ). m.p. $279-281{ }^{\circ} \mathrm{C}$ (decomp.); IR (KBr) $v_{\max } / \mathrm{cm}^{-1}: 3100-2300\left(\mathrm{~N}-\mathrm{H}\right.$ stretch, $\left.\mathrm{H}_{3} \mathrm{~N}^{+}\right)$, 2901, 2848 (C-H), 1636 (N-H bend) 1579, 1401 $\left(\mathrm{COO}^{-}\right)$. HRMS: calcd. for $\mathrm{C}_{13} \mathrm{H}_{21} \mathrm{NO}_{2}[\mathrm{M}+\mathrm{H}]^{+}$: 224.1645; found at $\mathrm{m} / \mathrm{z} 224.1646$. To obtain the NMR data compound 3 was converted into the water soluble hydrochloride form. Product 3 was suspended in water and treated with $2 \mathrm{M} \mathrm{HCl}(\mathrm{pH} \sim 1)$. Aqueous solution was saturated with brine and extracted with ethyl acetate. After removal of solvent product 3 (in hydrochloride form) was isolated as a white solid contaminated with sodium chloride. IR $(\mathrm{KBr}) v_{\max } / \mathrm{cm}^{-1}: 3300$ 2500 (O-H, N-H stretch), 2909, 2865, 2848 (C-H), $1726(\mathrm{C}=\mathrm{O}), 1629,1531\left(\mathrm{~N}-\mathrm{H}\right.$ bends). ${ }^{1} \mathrm{H}$ NMR $\left(\mathrm{D}_{2} \mathrm{O}\right)$ $\delta /$ ppm: 3.30-3.05 (m, 3H, CH- $\alpha, \mathrm{CH}_{2} \mathrm{NH}_{2}$ ), 1.93-1.56 $(\mathrm{m}, 15 \mathrm{H}, \mathrm{Ad}) .{ }^{13} \mathrm{C}$ NMR $\left(\mathrm{D}_{2} \mathrm{O}\right): 177.78(\mathrm{CO}), 44.94$ $(\mathrm{CH}-\alpha), 43.91(\mathrm{CH}, \mathrm{Ad}), 39.24\left(\mathrm{CH}_{2} \mathrm{NH}_{2}\right), 38.21,38.12$, 37.37, 31.19, $30.78\left(\mathrm{CH}_{2}, \mathrm{Ad}\right), 30.41,28.41,27.44$, $27.27(\mathrm{CH}, \mathrm{Ad})$. HRMS: calcd. for $\mathrm{C}_{13} \mathrm{H}_{21} \mathrm{NO}_{2} \mathrm{M}^{+}$: 224.1645; found at $\mathrm{m} / \mathrm{z} 224.1644$.

\section{X-ray Structural Analysis of 1}

Single crystals for X-ray analysis of $\mathbf{1}$ were obtained by recrystallization of the compound from a ethanol/water mixture. A suitable crystal was glued to a thin glass needle. The single-crystal X-ray diffraction data were collected at room temperature by $\omega$-scans on an Oxford Diffraction Xcalibur 3 CCD diffractometer with graphite-monochromated Mo- $K_{\alpha}$ radiation $(\lambda=0.71073 \AA)$. The data reduction was performed using the CrysAlis software package. ${ }^{19}$ Solution, refinement and analysis of the structure was done using the programs integrated in the WinGX system. ${ }^{20}$ The structure was solved by direct methods using SIR97. ${ }^{21}$ The refinement procedure was performed by the full-matrix least-squares method based on $F^{2}$ against all reflections with the program SHELXL-97. ${ }^{22}$ All non-hydrogen atoms were refined anisotropically. Hydrogen atoms were placed in calculated positions and refined using the riding model. Geometry calculations were done using PLATON, ${ }^{23}$ 
Table 1. Crystallographic data for compound 1

\begin{tabular}{|c|c|}
\hline Empirical formula & $\mathrm{C}_{15} \mathrm{H}_{19} \mathrm{NO}_{2}$ \\
\hline$M_{\mathrm{r}}$ & 245.31 \\
\hline$T / \mathrm{K}$ & 293 \\
\hline Crystal colour, habit & colourless, prism \\
\hline Crystal size $/ \mathrm{mm}^{3}$ & $0.12 \times 0.24 \times 0.46$ \\
\hline Crystal system & Monoclinic \\
\hline Space group & $P 2{ }_{1} / n$ \\
\hline \multicolumn{2}{|l|}{ Unit cell parameters } \\
\hline$a / \AA$ & $6.9823(4)$ \\
\hline$b / \AA$ & $18.0046(10)$ \\
\hline$c / \AA$ & $10.4542(7)$ \\
\hline$\beta /{ }^{\circ}$ & $91.757(6)$ \\
\hline$V / \AA^{3}$ & $1313.62(14)$ \\
\hline$Z$ & 4 \\
\hline$D_{\text {calc }} / \mathrm{g} \mathrm{cm}^{-3}$ & 1.240 \\
\hline$\mu / \mathrm{mm}^{-1}$ & 0.082 \\
\hline$F(000)$ & 528 \\
\hline Total data & 8276 \\
\hline Number of unique data & 2273 \\
\hline Number of data $\left[F_{\mathrm{o}} \geq 4 \sigma\left(F_{\mathrm{o}}\right)\right]$ & 1458 \\
\hline Number of parameters & 164 \\
\hline$R_{1}{ }^{(\mathrm{a})},\left[F_{\mathrm{o}} \geq 4 \sigma\left(F_{\mathrm{o}}\right)\right]$ & 0.0687 \\
\hline$w R_{2}^{(\mathrm{b})}$ & 0.1781 \\
\hline Goodness of fit on $F^{2}, S$ & 1.04 \\
\hline Min. and max. electron density / e $\AA^{-3}$ & $-0.38,0.50$ \\
\hline
\end{tabular}

while the structure drawings were prepared using PLATON and MERCURY ${ }^{24}$ programs. The crystallographic data are summarized in Table 1.

\section{RESULTS AND DISCUSSION}

The precursor in the synthesis of adamantane-derived $\beta$-amino acid was ethyl adamant-2-ylidenecyanoacetate (1). Compound 1 was prepared by the condensation of 2-adamantanone with ethyl cyanoacetate, according to Cope's procedure (Scheme 1) in excellent yield. ${ }^{25}$ Compound $\mathbf{1}$ was previously used as the precursor in the synthesis of adamantane-based $\alpha$-amino acid, (adamant2-yl)glycine, and it is also known as a precursor of adamantane spiro-3'-pyrrolidines which show antiviral acitivities. $^{18}$ The crystal structure of ethyl adamant-2ylidenecyanoacetate (1) was determined and is described in this paper for the first time.

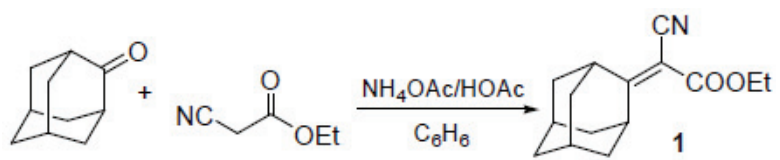

Scheme 1. Preparation of ethyl adamant-2-ylidenecyanoacetate (1).

\section{X-ray Analysis of Ethyl Adamant-2-ylidenecyano- acetate (1)}

The molecular geometry, as determined by X-ray analysis, and the atom labelling scheme of $\mathbf{1}$ is shown in Fig. 1, while the unit cell packing is illustrated in Fig. 2. The selected bond distances and angles are given in Table 2. The values of bond distances and angles are similar to those found in other related compounds. ${ }^{26-29}$ The molecular structure of $\mathbf{1}$ is characterized by adamantylidene and ethyl cyanoacetate moieties.

The adamantane unit consists of four cyclohexanes fused with each other, all approaching the ideal chair conformations. The Cambridge Structural DataBase, CSDB ${ }^{30}$ search using the ConQuest Version 1.14, gave 34 structures containing the adamantylidene unit with the $\mathrm{C}=\mathrm{C}$ double bond in the range of 1.319 $1.441 \AA$. The $\mathrm{C} 1=\mathrm{C} 11$ double bond in $\mathbf{1}$ has a length of 1.352(4) A. Substitution at C1 has an influence on the $\mathrm{C} 2-\mathrm{C} 1-\mathrm{C}$ 9 angle which is the largest one in the adamantne unit being $111.9(2)^{\circ}$ and also on the $\mathrm{C} 1-\mathrm{C} 2$ and $\mathrm{C} 1-\mathrm{C} 9$ bond lengths which are the shortes ones in that unit. Analysis of the structures from CSDB resulted in the range of $109.3^{\circ}$ to $113.6^{\circ}$ for the mentioned angle, with a mean value of $111.6^{\circ}$ which is very close to the value found in $\mathbf{1}$. In the DataBase there are only 2 structures with a methylacetate substituent: two polymorphs of dimethyl 2,3-bis(tricyclo[3.3.1.13,7]dec-2-ylidene)butanedionate. $^{28}$ There is only one structure having a cyano group as a substituent: in 2-adamanthylidene

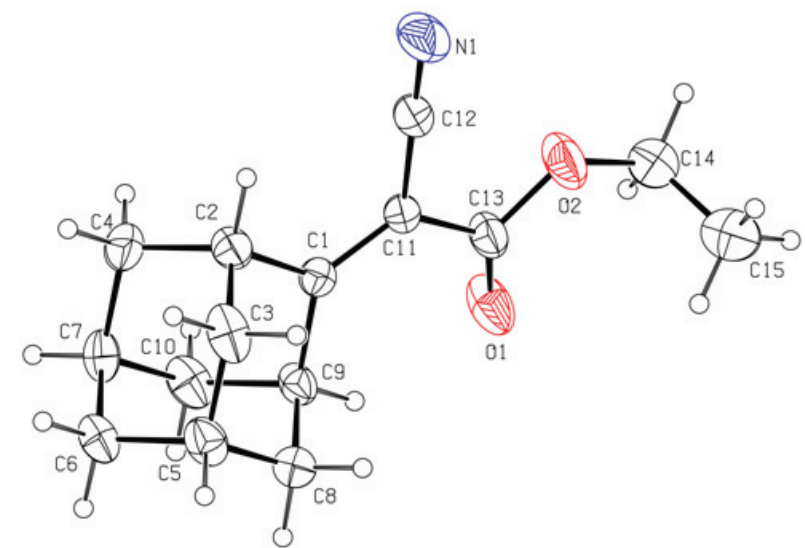

Figure 1. The molecular structure of 1. Displacement ellipsoids are drawn at the $30 \%$. 


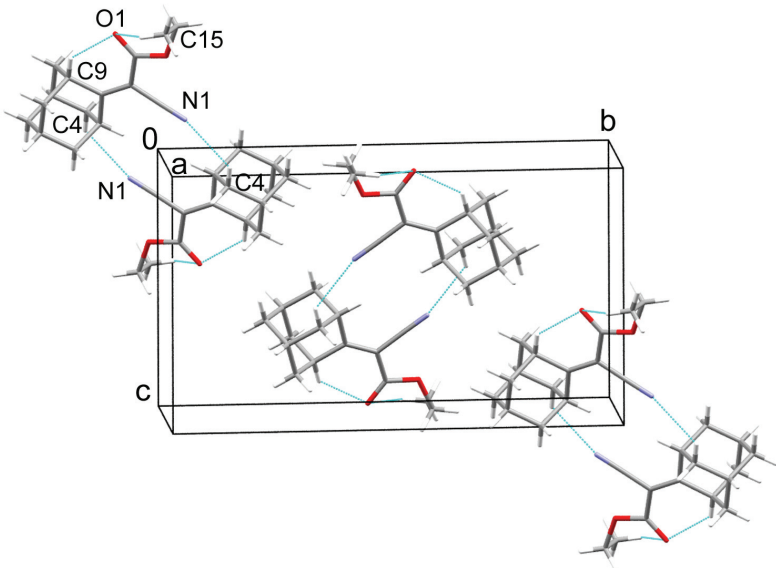

Figure 2. The crystal packing of molecules in the unit cell. Intramolecular $\mathrm{C} 9-\mathrm{H} 9 \cdots \mathrm{O} 1$ and $\mathrm{C} 15-\mathrm{H} 15 \mathrm{~B} \cdots \mathrm{O} 1$ and intermolecular $\mathrm{C} 4-4 \mathrm{~A} \cdots \mathrm{N} 1$ contacts are shown by dashed lines.

malondinitrile there are two cyano groups on $\mathrm{C} 11 .{ }^{31}$ In $\mathbf{1}$ there is some electron delocalization effecting bonds $\mathrm{C} 11-\mathrm{C} 12$ and $\mathrm{C} 11-\mathrm{C} 13$ which are shortened in relation to a single bond, and also effecting bonds N1-C12 and $\mathrm{C} 1-\mathrm{C} 11$ which are slightly lengthened in relation to formal triple and double bonds, respectively. A similar delocalization was found in the above mentioned compound where the authors attributed $10 \%$ to this effect.

There are no classical hydrogen bonds in the crystal structure. Weak intramolecular hydrogen bonds $\mathrm{C} 9-\mathrm{H} 9 \cdots \mathrm{O} 1$ and $\mathrm{C} 15-\mathrm{H} 15 \mathrm{~B} \cdots \mathrm{O} 1$ are present $(d(\mathrm{C} 9 \cdots \mathrm{O} 1)=2.976(4) \AA$ and $d(\mathrm{C} 15 \cdots \mathrm{O} 1)=3.167(5) \AA)$. The unit cell packing is controlled by a pair of weak intermolecular electrostatic $\mathrm{C} 4-\mathrm{H} 4 \mathrm{~A} \cdots \mathrm{N} 1$ contacts connecting molecules into centrosimetical dimers at a

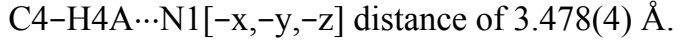

The crystal packing of the related compound ${ }^{28}$ also shows only weak intermolecular $\mathrm{C}-\mathrm{H} \cdots \mathrm{O}$ interactions.

The knowledge of the structure of ethyl adamant2-ylidenecyanoacetate $\mathbf{1}$ may be useful for the prediction of the outcome of enantioselective syntheses of $\alpha$ - or $\beta$-amino acids. Furthermore, it can be useful in possible chemical modifications of compound 1 (reductions, hydrolysis or click-reactions) that could be utilized for the preparation of pharmaceutically interesting compounds.

\section{Synthesis of the Adamantane $\beta$-Amino Acid (3)}

The efficient preparation of the novel adamantanecontaining $\beta$-amino acid is described in Scheme 2. Unsaturated cyanoester 1 was reduced to ethyl 2-(adamant-2-yl)-3-aminopropanoate (2) by catalytic hydrogenation, using $10 \% \mathrm{Pd} / \mathrm{C}$ catalyst in strong acidic conditions (4 equivalents of concentrated $\mathrm{HCl}$ ). Hydrogen pressure of 4 PSI at room temperature was appropriate for the reduction of the carbon-carbon double bond and the cyano group. Hydrochloric acid was added to prevent the generation of byproducts which could result if the product of reduction, primary amine (2), reacts with the intermediate imine. Under the given reaction conditions only traces of the unreacted cyanoester $\mathbf{1}$, and none of the possible byproducts, were observed by TLC monitoring. The reaction time was optimized and after $6 \mathrm{~h}$ a high yield (85\%) was achieved. Prolonged reaction time did not increase the yield. Unreacted compound 1 can be easily removed by extraction from the acidic reaction mixture and then reused. The resulting chemical transformation was confirmed by spectral data (MS, NMR and IR). The efficacy of reduction was clearly confirmed by the absence of the characteristic signals in IR and ${ }^{13} \mathrm{C}$ NMR spectra belonging to the $\mathrm{CN}$ group and $\mathrm{C}=\mathrm{C}$ bonds.

Racemic amino acid 3, 2-(adamant-2-yl)-3aminopropanic acid, was obtained in high yield (90\%) after the saponification of the ester 2. Basic reaction mixture was treated with $\mathrm{HCl}$ (aq) to obtain the neutral $\beta$-amino acid. At $\mathrm{pH} \sim 6$ compound 3 was in a zwitterionic form, insoluble in water. IR and MS data support the structure of compound 3. The carboxylate ion of zwitterion 3 gives two typical bands in the IR spectra: a strong, asymmetrical stretching band at $1579 \mathrm{~cm}^{-1}$ and a

Table 2. The selected interatomic distances $(\AA)$ and angles ( $\left.{ }^{\circ}\right)$ for compound $\mathbf{1}$

\begin{tabular}{ll}
\hline $\mathrm{O} 1-\mathrm{C} 13$ & $1.195(4)$ \\
$\mathrm{O} 2-\mathrm{C} 13$ & $1.338(4)$ \\
$\mathrm{O} 2-\mathrm{C} 14$ & $1.511(5)$ \\
$\mathrm{N} 1-\mathrm{C} 12$ & $1.141(5)$ \\
$\mathrm{C} 1-\mathrm{C} 2$ & $1.502(4)$ \\
$\mathrm{C} 1-\mathrm{C} 9$ & $1.503(4)$ \\
$\mathrm{C} 1-\mathrm{C} 11$ & $1.352(4)$ \\
$\mathrm{C} 11-\mathrm{C} 12$ & $1.437(4)$ \\
$\mathrm{C} 11-\mathrm{C} 13$ & $1.485(4)$ \\
$\mathrm{C} 14-\mathrm{C} 15$ & $1.431(7)$ \\
$\mathrm{C} 13-\mathrm{O} 2-\mathrm{C} 14$ & $117.4(3)$ \\
$\mathrm{C} 2-\mathrm{C} 1-\mathrm{C} 9$ & $111.9(2)$ \\
$\mathrm{C} 2-\mathrm{C} 1-\mathrm{C} 11$ & $122.6(2)$ \\
$\mathrm{C} 9-\mathrm{C} 1-\mathrm{C} 11$ & $125.4(2)$ \\
$\mathrm{N} 1-\mathrm{C} 12-\mathrm{C} 11$ & $179.2(3)$ \\
$\mathrm{O} 1-\mathrm{C} 13-\mathrm{O} 2$ & $123.0(3)$ \\
$\mathrm{O} 1-\mathrm{C} 13-\mathrm{C} 11$ & $127.2(3)$ \\
$\mathrm{O} 2-\mathrm{C} 13-\mathrm{C} 11$ & $109.8(3)$ \\
$\mathrm{O} 2-\mathrm{C} 14-\mathrm{C} 15$ & $104.7(4)$ \\
$\mathrm{C} 1-\mathrm{C} 11-\mathrm{C} 12$ & $119.3(3)$ \\
$\mathrm{C} 1-\mathrm{C} 11-\mathrm{C} 13$ & $125.8(3)$ \\
$\mathrm{C} 12-\mathrm{C} 11-\mathrm{C} 13$ & $115.0(2)$ \\
$\mathrm{O} 1-\mathrm{C} 13$ & $1.195(4)$ \\
$\mathrm{O} 2-\mathrm{C} 13$ & $1.338(4)$ \\
\hline
\end{tabular}




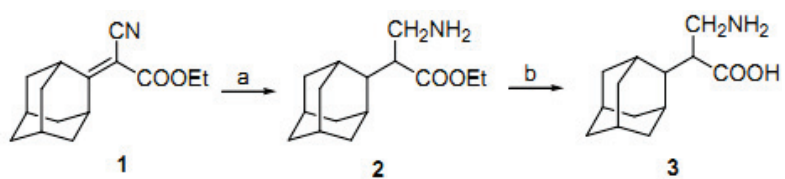

Scheme 2. Preparation of the adamantane $\beta$-amino acid; (a) $40 \mathrm{PSI}, 10 \% \mathrm{Pd} / \mathrm{C}, \mathrm{MeOH}$; (b) i) $2 \mathrm{M} \mathrm{NaOH}$ (aq)/dioxane, ii) $2 \mathrm{M} \mathrm{HCl}$ (aq).

weaker, symmetrical stretching band at $1401 \mathrm{~cm}^{-1}$. A broad, strong $\mathrm{NH}_{3}{ }^{+}$stretching band in the 3100$2300 \mathrm{~cm}^{-1}$ region also supports the zwitterionic structure of 3 . To obtain the NMR data 3 was converted into the water soluble hydrochloride form. IR and NMR spectra of the hydrochloride displayed the expected signals. Therefore, the structure of the novel adamantane $\beta$-amino acid was undoubtedly confirmed.

\section{CONCLUSION}

Preparation and characterization of novel adamantanederived $\beta$-amino acid, 2-(adamant-2-yl)-3-aminopropanic acid, is reported. The amino acid was synthesized in only three steps with very good overall yield (70 \%). In the first step ethyl adamant-2-ylidenecyanoacetate (1) was prepared by the condensation of 2-adamantanone and ethyl cyanoacetate and its crystal structure was determined. Knowledge of this crystal structure can be useful in an enantioselective synthesis of adamantane $\alpha$ - or $\beta$-amino acids. Unsaturated cyanoester 1 was converted to ethyl 2-(adamant-2-yl)-3-aminopropanoate (2). In the same step carbon-carbon bond and cyano group were efficiently reduced by catalytic hydrogenation in strong acidic conditions. The desired racemic amino acid was obtained after ester hydrolysis and it was fully characterized. The described amino acid will be used as a building block in the preparation of potentially biologically active peptides.

Supplementary Materials. CCDC 888912 contains the supplementary crystallographic data for this paper. These data can be obtained free of charge via www.ccdc.cam.ac.uk/data request/cif, or by e-mailing to data request@ccdc.cam.ac.uk, or by contacting The Cambridge Crystallographic Centre, 12, Union Road, Cambridge CB2 1EZ, UK; fax: +44 1223 336033 .

Acknowledgements. We wish to thank the Ministry of Science, Education and Sports of the Republic of Croatia for support of this work (projects 119-1191344-3121 and 119-11930791084) .

\section{REFERENCES}

1. J. Liu, D. Obando, V. Liao, T. Lifa, and R. Codd, Eur. J. Med Chem. 46 (2011) 1949-1963.
2. N. Bodor, A. A. El-Koussi, M. Kano, and M. M. Khalifa, J. Med. Chem. 31 (1988) 1651-1656.

3. A. J. Lin, M. Lee, and D. L. Klayman, J. Med. Chem. 49 (1989) 1249-1252.

4. H. S. Overkleeft, G. H. Renkema, J. Neele, P. Vianello, I. O. Hung, A. Strijland, A. M. van der Burg, G. J. Koomen, and J. M. Aerts, J. Biol. Chem. 273 (1998) 26522-26527.

5. J. Liu, D. Obando, L. G. Schipanski, L. K. Groebler, P. K. Witting, D. S. Kalinowski, D. R. Richardson, and R. Codd, J. Med. Chem. 53 (2010) 1370-1382.

6. D. Kim Quang and R. Schwyzer, Helv. Chim. Acta 64 (1981) 2084-2089.

7. Š. Horvat, K. Mlinarić-Majerski, Lj. Glavaš-Obrovac, A. Jakas, J. Veljković, S. Marczi, G. Kragol, M. Roščić, M. Matković, and A. Milostić-Srb, J. Med. Chem. 49 (2006) 3136-3142.

8. S. Tanabe, Y. Shishido, Y. Nakayama, M. Furushiro, S. Hashimoto, T. Terasaki, G. Tsujimoto, and T. Yokokura, Pharmacol. Biochem. Be. 63 (1999) 549-553.

9. B. Vranešić, J. Tomašić, S. Smerdel, D. Kantoci, and F. Benedetti, Helv. Chim. Acta 76 (1993) 1752-1758.

10. R. Ribić, L. Habjanec, B. Vranešić, R. Frkanec, and S. Tomić, Chem. Biodiv. 9 (2012) 777-788.

11. K. Hsieh, T. R. LaHann, and R. C. Speth, J. Med. Chem. 32 (1989) 898-903.

12. H. Josien, A. Martin, and G. Chassiang, Tetrahedron Lett. 32 (1991) 6547-6550.

13. H. Josien, S. Levielle, A. Brunissen, M. Saffroy, Y. Torrens, J. - C. Beaujouan, J. Glowinski, and G. Chassaing, J. Med. Chem. 37 (1994) 1586-1601.

14. J. Clariana, S. García-Granda, V. Gotor, A. Gutiérrez-Fernández, A. Luna, M. Moreno-Manãs, and A.Vallribera, Tetrahedron: Asymmetry 11 (2000) 4549-4557.

15. B. Gašpert, S. Hromadko, and B. Vranešić, Croat. Chem. Acta 48 (1976) 169-178.

16. H. T. Nagasawa, J. A. Erberling, and F. N. Shirota, J. Med. Chem. 16 (1973) 823-826.

17. F. N. Stepanov and Y. I. Srebrodolskii, Zh. Org. Khim. 2 (1966) 1612-1615.

18. K. Lundahl, J. Schut, J. L. M. A. Schlatmann, G. B. Pearels, and A. Peters, J. Med. Chem. 15 (1972) 129-132.

19. Oxford Diffraction, CrysAlis Software system, Version 1.171.33.41, 2009.

20. L. J. Farrugia, J. Appl. Crystallogr. 32 (1999) 837-838.

21. A. Altomare, M. C. Burla, M. Camalli, G. L. Cascarano, C. Giacovazzo, A. Guagliardi, A. G. G. Moliterni, G. Polidori, and R. Spagna, J. Appl. Crystallogr. 32 (1999) 115-119.

22. G. Sheldrick, Acta Crystallogr. Sect. A 64 (2008) 112-122.

23. A. L. Spek, J. Appl. Crystallogr. 36 (2003) 7-13.

24. I. J. Bruno, J. C. Cole, P. R. Edgington, M. K. Kessler, C. F. Macrae, P. McCabe, J. Pearson, and R. Taylor, Acta Crystallogr., Sect. B 58 (2002) 389-397.

25. A. C. Cope, C. M. Hoffman, C. Wyckoff, and E. Hardenbergh, J. Am. Chem. Soc. 63 (1941) 3452-3456.

26. M. A. Wolak, R. C. Finn, R. S. Rarig Junior, C. J. Thomas, R. P. Hammond, R. R. Birge, J. Zubieta, and W. J. Lees, Acta Crystallogr., Sect. C $\mathbf{5 8}$ (2002) o389-0393.

27. M. Kaftory, Yu. Goldberg, S. Z. Goldberg, and M. Botoshansky, Acta Crystallogr., Sect. C 54 (1998) 683-687.

28. J. W. Bats, M. A. Grundl, and A. S. K. Hashimi, Acta Crystallogr., Sect. C 57 (2001) 653-656.

29. S. S. Al-Shihry and A. Linden, Acta Crystallogr., Sect. C 59 (2003) $\mathrm{m} 40-\mathrm{m} 42$

30. F. H. Allen, Acta Crystallogr., Sect. B 58 (2002) 380-388.

31. A. Kutoglu and R. Allmann, Cryst. Struct. Comm. 4 (1975) 57-60. 